Ljubljana

\title{
PRONOUNS AND THE PROBLEM OF REFERENCE IN TRANSFORMATIONAL GRAMMAR
}

The problem of reference is one of the main problems in transformational grammar. It does not concern only the pronominalization and reflexivization rules (both transformational and interpretive) but also many other rules, such as, for instance, deletion rules, movement rules, etc. Inspite of its importance for transformational grammar as a whole the problem of reference is still largely unsolved. Attempts to deal with it have been only partially successful; several points still have to be explained before a complete solution can be found.

In what follows a critical survey of some approaches to the problem of reference is given.

\section{The Referential Index Approach}

1.0 This approach, commonly known as the Index Approach, was first put forward by Chomsky (1965). He suggests that "... certain lexical items are designated as referential ..."1 and then proposes that "... by a general convention each occurrence of a referential item is assigned a marker ${ }^{2}$, say an integer, as a feature". 3 In this way reference is marked in the deep structure (DS) by means of lexical features. The Index Approach has been most frequently used in the transformational rules of pronominalization, reflexivization, Equi-NP deletion and relative clause formation.

1.1. Let us now examine in greater detail how the Index Approach can work within the transformational theory of pronouns and reflexives.

According to the transformational theory anaphoric pronouns and reflexives are not generated in the DS but are derived transformationally from underlying noun phrases (NP's). Reference is marked in the DS by means of indices on NP's. The semantic component will interpret two NP's as being coreferential if, and only if, they have been assigned the same index in the DS.

For instance consider (1):

(1) Mary said that Mary was tired.

$$
\mathrm{NP}_{1} \quad \mathrm{NP}_{2}
$$

Let the referential indices be $\underline{i}$ and $\mathbf{j}$.

If $\mathrm{NP}_{1}$ is assigned the referential index $\underline{i}$ and $\mathrm{NP}_{2}$ is assigned the same referential index $i$, then $\mathrm{NP}_{1}$ is coreferential with $\mathrm{NP}_{2}$. PRONOMINALIZATION therefore takes place, generating (2):

(2) Mary said that she was tired.

The semantic component then interprets Mary and she as having the same reference. 
With respect to REFLEXIVIZATION the Index Approach works in a similar way, the only difference being that there is an additional condition, besides the coreferentiality condition: $\mathrm{NP}_{1}$ and $\mathrm{NP}_{2}$ must be in the same simple sentence. Thus, for instance, (3) is derived from (4):

(3) John hurt himself.

(4) John ${ }_{i}$ hurt $J$ hon $_{i}$. $\mathrm{NP}_{1} \quad \mathrm{NP}_{2}$

$$
\begin{aligned}
& \mathrm{NP}_{1} \text { is coreferential with } \mathrm{NP}_{2} \\
& \mathrm{NP}_{1} \text { and } \mathrm{NP}_{2} \text { are in the same } \\
& \text { simplex } \mathrm{S} \\
& \text { REFLEXIVIZATION } \Longrightarrow(3)
\end{aligned}
$$

1.2 On first sight it would seem that the Index Approach can successfully deal with the problem of reference, at least as far PRONOMINALIZATION and REFLEXIVIZATION are concerned. However, there exist a number of cases for which this approach proves to be inadequate.

1.2.1 Lakoff (1968) discussing the problem of reference at considerable length, presents several cases which show the inadequacy of the Index Approach on both syntactic and semantic grounds.

1.2.1.1 Lakoff's first counterexample to the Index Approach involves what he calls "the participant - observer distinction". According to Lakoff sentences like (5) have two different readings.

(5) John dreamed that he was robbing the bank.

On the first reading (the participant reading) John dreamed that he was actually taking part in the bank robbery, whereas on the second reading (the observer reading) John dreamed that he was observing himself committing the bank robbery. The participant-observer distinction, hidden at first sight in sentence (5), can be perceived much more readily in sentences where it corresponds to a syntactic distinction, as for instance in (6) and (7):

(6) John imagined robbing the bank. (participant)

(7) John imagined himself robbing the bank. (observer)

Lakoff claims that sentences such as (6) and (7) cannot be accounted for by means of the Index Approach.

Both (6) and (7) have the same DS (8):

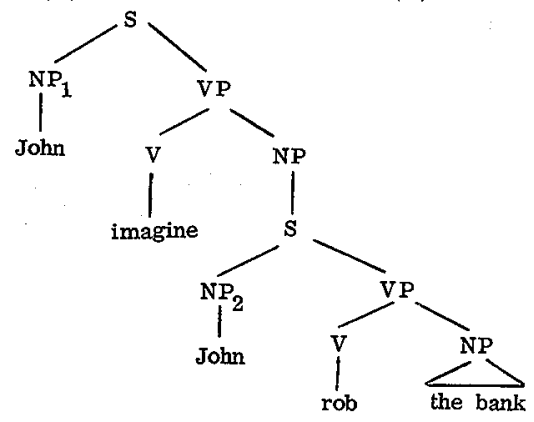


In order to derive (6) EQUI-NP-DELETION must be applied. However, this can only be done if $\mathrm{NP}_{1}$ is identical to the participant $\mathrm{NP}_{2}$ but not to the observer $\mathrm{NP}_{2}$.

In the derivation of (7) REFLEXIVIZATION is applied after SUBJECT

RAISING has made the subject of rob the superficial object of imagine. To make the application of REFLEXIVIZATION possible, $\mathrm{NP}_{1}$ must be considered identical to the observer $\mathrm{NP}_{2}$.

Within the Index Approach the identity of NP's can be marked, but there is no way of indicating whether an NP is identical with a participant NP or whether it is identical with an observer NP. The cases discussed above are obviously beyond the scope of the Index Approach.

1.2.1.2 Lakoff mentions one further class of counterexamples to the Index Approach. These counterexamples involve a curious occurrence of ungrammaticality in pairs of sentences like the following:

(9) Mary wants to buy a car and she wants to drive it.

(10) * Mary wants to buy a car and she will drive it.

(9) is derived from (11) and (10) from (12):

(11) Mary $y_{j}$ wants to buy a car $\frac{\mathrm{Nar}_{\mathbf{i}}}{\mathrm{NP}_{1}}$ and $\mathrm{Mary}_{\mathbf{j}}$ wants to drive $\frac{\mathrm{a} \mathrm{car}_{\mathbf{i}}}{\mathrm{NP}_{2}}$

(12) $\mathrm{Mary}_{\mathrm{j}}$ wants to buy a car $\frac{\mathrm{a}}{\mathrm{NP}}$ and $\mathrm{Mary}_{\mathbf{j}}$ will drive $\frac{a \text { car }_{\mathrm{i}}}{\mathrm{NP}_{2}}$

In the DS' $s$ of both (9) and (10) the coreferentiality condition on $\mathrm{NP}_{1}$ and $\mathrm{NP}_{2}$ is met and PRONOMINALIZATION can therefore apply, replacing $\mathrm{NP}_{2}$ with a corresponding pronoun it. Yet (10) is ungrammatical. If the Index Approach is correct then why is this so?

1.2.2 The Index Approach obviously does not provide a satisfactory solution of the problem of reference. Chomsky (1965) himself points out that "... interesting problems arise when the referential items are plural". 4 Unfortunately Chomsky does not give any examples to show what these "interesting problems" might be. That plural NP's pose difficulties for the Index Approach has been noted also by Partee (1973), again with no examples given. In addition to plural NP's she considers that quantified NP's can cause problems for the Index Approach, too. She does provide some pairs of sentences like (13) and (14) but gives no explanation as to why such sentences give rise to difficulties.

(13) Every philosopher argues with himself.

(14) Every philosopher argues with every philosopher. $\} \quad(44 \mathrm{a}, \mathrm{b})]$

A possible explanation can be obtained by considering the DS's of the two sentences. It turns out that both (13) and (14) have the same DS, (15): 
(15)

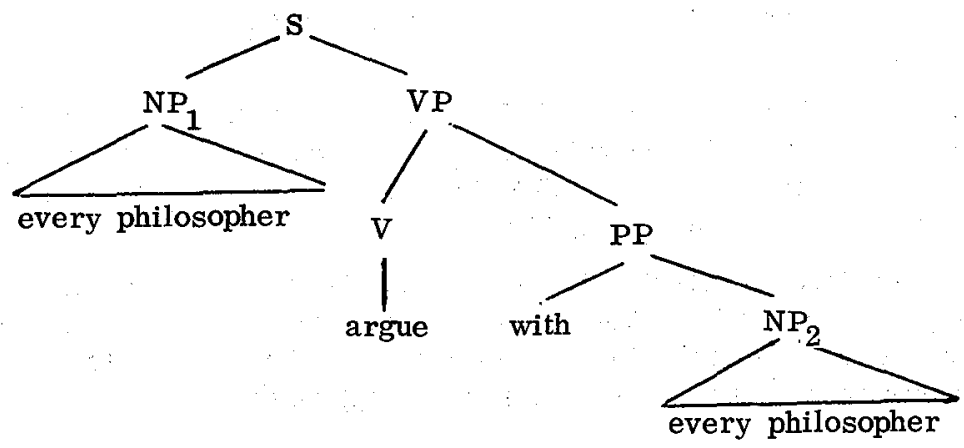

The main difficulty lies in the fact that in order to derive (13) $\mathrm{NP}_{1}$ and $\mathrm{NP}_{2}$ would have to be marked coreferential, whereas for the derivation of (14) they would have to be marked non-coreferential. As the DS is the same for both sentences it is not at all clear how the referential index system could mark the same two NP's once as coreferential and once as non-coreferential.

1.2.3 The next class of problematic cases to be dealt with involves sentences like $(16)$ :

(16) The girl hurt her.

In (16) the girl and her are without doubt non-coreferential. The DS of (16) is (17):

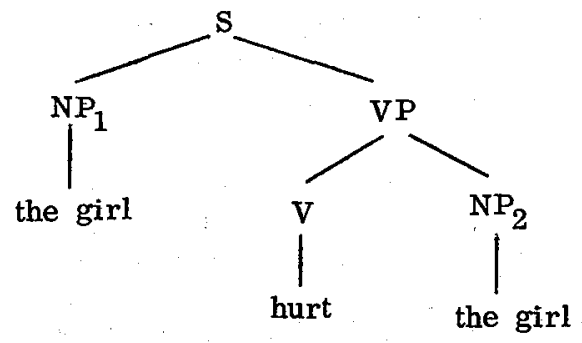

The referential indices of the two NP's have to be identical if PRONOMINALIZATION is to apply. But, as has been pointed out above, the two NP's are non-coreferential. So sentences like (16) cannot be derived at all within a theory of pronouns and reflexives based on the Index Approach. And yet (16) is perfectly grammatical and belongs to one of the most common types of English sentences.

\section{The Interpretive Approach}

2.0 According to the interpretive theory pronouns and reflexives are generated in the DS and their reference is marked by semantic rules of interpretation. The 
need to use the Index Approach is thus avoided but this does not mean to say that a semantic reference determining mechanism proposed by the interpretive theory of pronouns and reflexives could fully cope with the problem of reference.

2.1 Let us now take the examples put forward by Lakoff (1968) again in order to see whether they can be solved by means of the Interpretive Approach.

First consider (5):

(5) John dreamed that he was robbing the bank.

The pronoun he is now present in the DS of (5). John and he can optionally be interpreted as coreferential since (5) satisfies the conditions for the operation of the interpretive pronominalization rule. ${ }^{5}$ However, there seems to be no way for the semantic reference determining mechanism to be able to mark the participant - observer distinction; the Interpretive Approach obviously cannot handle cases like (5) any better than the Index Approach.

The Index Approach failed to account for the difference between (6) and (7).

(6) John imagined robbing the bank. (participant)

(7) John imagined himself robbing the bank. (observer)

The Interpretive Approach on the other hand, is not able to relate (6) and (7) at all. Although (6) and (7) if taken individually, do not present any problems for the Index Approach, the latter cannot be considered satisfactory since it fails to perceive the relationship which is intuitively felt to exist between these two sentences. According to the interpretive theory of pronouns and reflexives (6) and (7) have different DS's; in the DS of (7) the lexical item under the node $\mathrm{NP}_{2}$ has the feature $\langle+\mathrm{REFL}\rangle$, whereas in the DS of (6) the lexical item under the same node has the feature $\langle+$ PRO〉 . Since the DS of (6) and (7) differ, the derived sentences, (6) and (7), also differ. Thus the distinction between (6) and (7) has been shown by the use of the Interpretive Approach, but not in a satisfactory way. This is because the difference shown between (6) and (7) is not based on the participant-observer distinction but instead on a distinction in the DS' $S$ of two sentences, thus completely obscuring the relationship which exists between (6) and (7).

As has been shown by Lakoff (1968) the ungrammaticality of sentences such as (10) cannot be explained within the transformational theory of pronouns and reflexives based on the Index Approach. No reason seems to be given for it within the interpretive theory either.

(9) Mary wants to buy a car and she wants to drive it.

(10) * Mary wants to buy a car and she will drive it.

The conditions which must be fulfilled for the interpretive pronominalization rule to be able to apply are satisfied in both (9) and (10). Therefore a car and it can be marked coreferential in both sentences. The reason for the ungrammaticality of (10) remains a mystery. 
2.2 Sentences such as (13) and (14) can be accounted for within the interpretive theory if taken individually, but like in cases (6) and (7) the relation existing between (13) and (14) is not perceived.

The problem of how to account for pairs of sentences which are clearly related obviously cannot be solved by simply ignoring the fact that the two sentences in a pair are related.

2.3 Cases like (16) can be handled by the Interpretive Approach but only if the interpretive reflexive rule ${ }^{6}$ is modified (Sheppard (1974)), as follows:

If $\mathrm{NP}_{1}$ and $\mathrm{NP}_{2}$ are in the same simplex $\mathrm{S}$, then $\mathrm{NP}_{2}$ can be coreferential with $\mathrm{NP}_{1}$ if and only if it is reflexive. OBLIGATORY

According to this rule $\mathrm{NP}_{1}$ (the girl) and $\mathrm{NP}_{2}$ (her) can be only marked non-coreferential.

We have seen that inspite of the fact that both existing theories of pronouns and reflexives, the transformational theory and the interpretive theory, involve the notion of reference neither of them can cope with all problems connected with it. For this reason several grammarians have been led to think that perhaps some other notion, instead of reference, is needed if a satisfactory treatment of pronominalization and reflexivization is to be obtained.

Two approaches adopting a notion other than reference now follow.

\section{The Counterpart Approach}

3.0 When discussing cases such as (5) - (7) and (9) - (10) Lakoff (1968) proposes that the notion of coreferentiality be replaced by that of counterpart. The notion of counterpart has been taken from a new form of modal logic, developed by David Lewis?. In contrast to the traditional forms of logic this new form lets two possible worlds be related in such a way that two entities in one world can correspond to one entity in the other. Lakoff suggests that this approach to logic be employed in order to solve cases like (5) - (7) and (9) - (10) since these sentences involve more than one possible world. The fact that they do is the very reason why such sentences present problems to both the Index and the Interpretive Approach.

In (5) John of the actual world in which he does his dreaming is split into two persons in the world of dream:

John the participant and John the observer.

Shematically the situation looks like this:

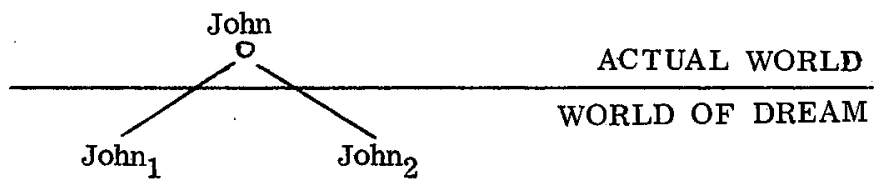


The problem of why ungrammaticality occurs in cases like (10) can also be explained in terms of two possible worlds. In (9) a car exists in the world of Mary's desires which is defined by Mary wants. The same world is involved in the second part of (9) since the latter again contains Mary wants. It follows that the car bought by Mary exists in this second possible world as well as in the first one. In other words, the car in the first half of the sentence has a counterpart in the second half of the sentence, so the pronoun it can be used when referring back to the car in the first half of the sentence.

In (10), however, two different possible worlds are related: the world of Mary's desires, in which the car bought by Mary exists, and the actual world, defined by will, in which the car Mary wants to buy does not exist. Therefore the car in the first half of the sentence does not have a counterpart in the second half the sentence, and consequently, the car in the first half of the sentence cannot be referred back to with the pronoun it. If it is, then ungrammaticality results, as in (10).

To demonstrate the usability of the Counterpart Approach, Lakoff considers some further examples which are unexplainable both within the transformational theory and within the interpretive theory of pronouns and reflexives:

(9a) Mary wants to buy a car and she intends to drive it.

(10a) * Mary intends to buy a car and she wants to drive it.

According to Lakoff the car in the world of Mary's desires has a counterpart in the world of Mary's intentions, but not vice versa. This would explain the ungrammaticality of (10a). Thus the entities that exist in the world of one's desires automatically exist in the world of one's intentions, but not vice versa. 8

On the basis of such cases, Lakoff concludes that the notion of counterpart, and not the notion of coreferentiality is relevant for pronominalization.

\section{The Formal Identity Approach}

4.0 Another approach to pronominalization which tries to avoid the notion of coreferentiality has been presented by Partee (1973). According to her pronominalization involves two processes: during the first process a repeated $N$ in an either definite or indefinite $\mathrm{NP}$ is reduced to the proform one $(\mathrm{s})$ and during the second the proform one(s) deleted after certain determiners. The referential noun identity is not relevant for either N-REDUCTION TO ONE(S) or for subsequent DELETION of ONE (S). The only requirement to be fulfilled is formal noun identity.

4.1 Anaphoric personal pronouns are assumed to be derived by the reduction of a repeated the $N$ to the one(s) followed by the deletion of one(s), leaving only the definite pronoun the under the NP node. Therefore anaphoric personal pronouns are considered to be the suppletive forms of the. ${ }^{9}$ 
4.1.1 Since personal pronouns are derived only from definite NP's there must be some process introducing definite articles which precedes what Partee calls "pronominalization proper". Definite articles are introduced by DEFINITIVIZATION. Partee points out that, unlike in the case of PRONOMINALIZATION, in the case of DEFINITIVIZATION the notion of coreferentiality plays an important role.

Another process which, according to Partee, precedes PRONOMINALIZATION is REFLEXIVIZATION. Here, once again, the problem of reference cannot be avoided; the application of REFLEXIVIZATION requires coreferentiality between the antecedent and the reflexivized NP. 10

4.1.2 According to the Formal Identity Approach pronouns can be generated both transformationally from underlying NP's by the processes described above and also in the DS, i.e. from underlying the one(s).

The first way of derivation corresponds to the transformational theory and the second to the interpretive theory. The only difference between the interpretive theory and the system suggested by Partee is that within the latter only the DS determiner the and the proform one(s) are present in DS and not all pronouns as is stated by the interpretive theory.

4.2 However, even the "combined" system proposed by Partee cannot handle the problematic cases presented in 1.2, p. 2 .

4.2.1 Sentences such as (16) clearly have a non-ambignous non-coreferential reading, but according to Partee's system (16) can be derived in two different ways:

(18) The girl hurt the one.

(19) The girl hurt the girl.

In (19) the first the $\mathrm{N}$ is formally identical to the second the $\mathrm{N}$, and yet, as mentioned above, they must not be considered coreferential. However, the condition of formal $\mathbf{N}$ - identity has been met, and since this is the only requirement for the application of N-REDUCTION TO ONE(S) the latter process takes place. Two non-coreferential NP's are not necessarily always accompanied by formally different modifiers, as can be seen in (19). Besides one all that is left in the second NP after N-REDUCTION TO ONE(S) has taken place is the, and therefore there is no way within the Formal Identity Approach by means of which the conversion of the one into her could be prevented. During the derivation of (16) the girl will thus be automatically turned into her and consequently coreferentiality between her and the preceding NP will be implied, inspite of the fact that in reality cases like (16) cannot have a coreferential reading.

4.2.2 Sentences such as (13) can be accounted for by the Formal Identity Approach since according to this approach the identity condition is not on the whole NP. Thus (13) can be derived from (20).

(13) Every philosopher argues with himself. 
(20) Every philosopher argues with the philosopher.

Sentence (14)

(14) Every philosopher argues with every philosopher,

however, presents the same difficulty for the Formal Identity Approach as sentence (19). The difficulty involves the false implication of coreferentiality.

4.2.3 Like the Index Approach and the Interpretive Approach, the Formal Identity Approach fails to account for pairs of sentences such as (9) and (10).

(9) Mary wants to buy a car and she wants to drive it.

(10) *Mary wants to buy a car and she will drive it.

Whereas the Index and the Interpretive Approach can account for the grammaticality of (9) but cannot account for the ungrammaticality of (10), the situation here is merely reversed.

The ungrammaticality of (10) can be explained since within the Formal Identity Approach the assumption has been made that an indefinite NP can be the antecedent only if it is 〈+specific > and not if it is 〈-specific〉.

A car in (10) is 〈-specific〉 and this is the reason for the ungrammaticality of this sentence. However, if this is correct, then how is it possible for (9) to be grammatical inspite of the fact that it includes the same $\langle$-specific NP 〉, a car? Since within the Formal Identity Approach the grammaticality of (9) cannot be accounted for, the relationship between the two sentences once again remains unexplained.

4.2.4 Finally, there seems to be no way in which cases involving participant-observer distinction such as (5) - (7) can be handled by the Formal Identity Approach.

\section{Conclusion}

5.0 During the discussion of the reference problem in $1 .-4$. above the following two facts have become obvious:

- Although both the transformational theory and the interpretive theory of pronouns and reflexives draw heavily on the notion of reference neither of them can provide an entirely adequate system for its representation.

- The importance (if any at all) of the role which reference plays with regard to pronominalization and reflexivization is by no means clear.

5.1.1 It has been shown that neither the Index nor the Interpretive Approach developed within the transformational theory and the interpretive theory respectively can handle cases like (4) - (7), (9) - (10), (13) - (14), (16). Sentences such as these occur frequently enough in standard English so they cannot be labelled as exceptional in order to justify either of the two approaches mentioned above. 
5.1.2 Furthermore, there exists a fact which bears more general significance than individual cases and therefore casts serious doubt on the validity of both the Index and the Interpretive Approach. This fact has to do with the definition of the notion of reference. The problem is that so far it has never been explicitly stated what exactly is meant by the terms "reference", "referential", "coreferential".

When Chomsky (1965) put forward the Index Approach he was at the same time well aware of the fact that "... there are problems in specifying the notion 'referential' properly". 11

Partee (1973) points out how difficult it is to define the notion of coreferentiality since "... in many cases the two coreferential NP's do not refer to the same physical object"12 as, for instance in (21):

(21) My home used to be in Baltimore, but now it's in Los Angeles. [Partee (131)].

Like the Index Approach the Interpretive Approach involves a vague notion of reference which is no more explicitly defined than within the former.

Thus with regard to the general question of what exactly "reference" is there is no reason for preferring either one of the two approaches to the other.

It is very difficult to imagine how an approach can have any hope of being satisfactory if the notion on which it is based is left unexplained. In particular, how can an adequate system of representing reference be worked out if it is not clear what reference really is?

5.2 We have seen that the Index Approach and the Interpretive Approach share almost the same good and bad points:

- they both involve an inexplicitly defined notion of reference

- neither of them can explain several classes of cases

- both of them appear to be satisfactory when dealing with reflexivization

On the whole the deficiencies of both approaches are large enough to raise serious doubt as to the importance of reference for pronominalization ad reflexivization.

In order to see whether or not such a doubt is justified and to estimate how important (if at all) reference is, we have considered two approaches to pronominalization and reflexivization, both of which negate the importance of reference: Lakoff's Counterpart Approach and Partee's Formal Identity Approach.

5.2.1 Lakoff's claim that the notion of counterpart, rather than the notion of reference, is of crucial importance for pronominalization and reflexivization has been strongly supported by cases simultaneously involving two possible worlds like (9) - (10) and (9a) - (10a). It has been shown in 3. p. 6 how these cases, unaccounted for by the Index and the Interpretive Approach, can be explained by the Counterpart Approach. 
However, the Counterpart Approach, such as it is, representes an attempt to construct a full approach which would give an adequate account of pronominalization and reflexivization, rather than a fully worked out approach. Lakoff himself points out some difficulties which arise in the Counterpart Approach:

- He suggests that the notion of counterpart, instead of the notion of reference, be incorporated into syntax, yet he notes that he has "... no clear idea at present how to integrate such a notion into syntax". ${ }^{13}$

- Lakoff also points out that although the Counterpart Approach can account for sentences like (9) - (10) and (9a) - (10a) it cannot handle the problem of the participant-observer distinction (see (5) - (7)).

- Furthermore, if the Counterpart Approach is to be used as a device for semantic representation then the existence of logical contradictions will be permitted in "possible worlds". Lakoff considers the sentence:

(22) I dreamed that I found a round square and that I sold it for a milion dollars. [Lakoff, (45)].

Lakoff maintains that contradictions such as "a round square" can perfectly well exist in "possible worlds". After all, (22) is a grammatical sentence and cases like (22) should not be considered as counterexamples to the Counterpart Approach.

This claim is, of course, debatable. Right or wrong, it nevertheless leads to an interesting conclusion: the novelty of the Counterpart Approach does not concern only the strictly "technical" sphere of pronominalization theory but also has significant consequences of more general kind that extend into the sphere of philosophy. This means that any attempt to justify and or improve the Counterpart Approach should take into consideration the problems arising on both the "technical" and the "philosophical" sides of this approach.

5.2.2 It has been shown that the Formal Identity Approach, the other approach which denies the significance of the notion of reference, runs into difficulties on a number of occasions.

5.2.2.1 Within the Formal Identity Approach there seems to be no way in which N-REDUCTION TO ONE(S) can be blocked in cases where the operation of this rule would result in a false implication of coreferentiality. (see 4.2.1, p. 8 and 4.2 .2 , p. 8 ).

5.2.2.2 The class of cases such as those presented by Lakoff (1968) (see 1.2.1, p.2) remains unaccounted for within the Formal Identity Approach as well as in the approaches based on the notion of reference.

5. 3 Our discussion of the problem of reference leads us to the following conclusion: although it is quite likely that the role which reference plays in pronominalization and reflexivization may not be as important as maintained by the Index and the Interpretive Approach, reference itself cannot be completely. ignored. There are several reasons for this: 
- if so far no adequate system of representing reference has been worked out this by no means indicates that reference itself is irrelevant for pronominalization and reflexivization.

- It is generally accepted that the notion of reference is of crucial importance for reflexivization. Since there are good reasons for considering reflexivization to be closely related to pronominalization 14 how can the claim that the notion of reference is of no significance in the case of pronominalization be justified? It is very hard to maintain that a notion, crucial for one particular phenomenon, is totally irrelevant for another which bears a great resemblance to the former.

- The attempt to base an approach to pronominalization exclusively on the formal identity of NP's has proved to be unsatisfactory in cases where a discrepancy exists between formal and referential identity. Morever, certain cases (e.g. Lakoff's examples) pose the same difficulty for the approach based on the formal identity of NP's as for the two approaches based on the notion of reference. Therefore the reasons for the existence of certain problems cannot be atributed simply to an overestimation of the importance of the role played by reference; even if the notion of reference is avoided such problems remain unsolved.

5.4 There seem to be two directions in which the search for anadequate account of pronominalization and reflexivization could proceed.

5.4.1 An attempt can be made to replace the notion of reference by another more, powerful notion. In this respect Lakoff's Counterpart Approach appears to show much promise.

Of course, the deficiencies of this approach, such as those mentioned by Lakoff (see 5.2.1, p.10), must be got rid of if the Counterpart Approach is to become capable of dealing with pronominalization and reflexivization in a completely satisfactory manner.

At least one of these deficiencies, the one which concerns the participant-observer distinction, turns out to be less serious if an idea, provided by Lakoff himself, is made use of: Lakoff mentions the possibility of introducing the new notions "participant counterpart" and "observer counterpart". Although Lakoff does not attribute any importance to this possibility it is not unreasonable to assume that by means of these two new notions the problem of participant-observer distinction might be solved.

It is therefore very likely that the Counterpart Approach, when improved or, rather, fully worked out, will be able to shed considerable light on the phenomena of pronominalization and reflexivization.

5.4.2 Another possibility which might lead to success in the search for an adequate account of pronominalization and reflexivization is implied within the treatment of these two phenomena as presented by Partee (1973) (see 4., p. 7). Although it has been shown that an adequate system of pronominalization rules 
cannot depend on the formal linguistic structure alone, it is well worth considering Partee's treatment since it takes one basic postulate from the transformational theory and one from the interpretive theory and combines them. (see 4.1 .2$, p. 8 ). This combination suggests that it might be possible to make another combination concerning formal and referential identity.

The new approach which is proposed here involves two main claims:

- The first claim is taken over, unmodified, from Partee's treatment of pronominalization: pronominalization is considered to consist of two processes: N-REDUCTION TO ONE(S) with the deletion of identical modifiers and the subsequent deletion of one(s) after certain determiners.

- The second claim is that N-REDUCTION TO ONE(S) takes place either under the condition of formal distinctness or under that of coreferentiality. This claim differs from the one made in Partee's treatment, according to which N-REDUCTION TO ONE(S) is conditioned by formal noun identity alone.

This second claim of the approach proposed here would provide a solution to one of the major problems in the Formal Identity Approach, i.e. that of false implication of coreferentiality resulting from the exclusively formal conditioning of N-REDUCTION TO ONE(S). Sentences like (14) and (19) are no problem now.

(14) Every philosopher argues with every philosopher.

(19) The girl hurt the girl.

In (14) and in (19) neither the condition of formal distinctness nor that of coreferentiality is met and therefore N-REDUCTION TO ONE(S), which would result in a false implication of coreferentiality, does not apply.

However, the question of how reference should be represented in the DS still remains to be solved. At present there exists only one system of representing reference in the DS, the referential index system, and this system has proved to be inadequate. As long as the appreach to pronominalization and reflexivization proposed here is not provided with a more adequate device for representing reference it will be difficult to evaluate it properly. Nevertheless, even such as it is now this approach implies something which might be of considerable significance for the future investigation of the phenomena of pronominalization and reflexivization: it shows that it is most likely that a consistent account of these two phenomena would have to involve the notion of reference.

\section{REFERENCES}

Bach, Emmon (1970): "Pronominalization", Linguistic Inquiry 1. 121-122.

Chomsky, Noam (1965): Aspects of the Theory of Syntax, M. I. T. Press, Cambridge.

Dougherty, Ray C. (1968): "An Interpretive Theory of Pronominal Reference", Foundations of Language 5. 488-519. 
Jackendoff, Ray C. (1968): "An Interpretive Theory of Pronouns and Reflexives", unpublished paper, M.I. T.

Lakoff, George P. (1968): "Counterparts or the Problem of Reference in Transformational Grammar", ISA Summer Meeting.

Langacker, Ronald W. (1966): "On Pronominalization and the Chain of Command in Modern Studies in English: Readings in Transformational Grammar, David Reibel and Sanford A. Schane (eds.), Prentice-Hall, Englewood Cliffs, N. J.

Lees, R. B. and E. S. Klima (1963): "Rules for English Pronominalization", Modern Studies in English, eds. Reibel and Schane, pp. 145-159, Prentice-Hall, Englewood Cliffs, N. J.

Partee Hall, Barbara (1973): "Pronominalization", in The Major Syntactic Structures of English, R. P. Stockwell, P. Schachter and B. Hall Partee, pp. 161-230, Holt, Rinehart and Winston, New York.

Postal, Paul (1966): "On So-Called Pronouns in English", Modern Studies in English, eds. Reibel and Schane, pp. 201-244, Prentice-Hall, Englewood Cliffs, N. J.

Ross, John Robert (1968): "On the Cyclic Nature of English Pronominalization" Modern Studies in English, eds. Reibel and Schane, pp. 187-200, Prentice-Hall, Englewood Cliffs, N. J.

Sheppard Milojević, Milena (1974): "Pronominalization and Reflexivization in Transformational Grammar", M.A. thesis, Filološki fakultet, Beograd.

Notes

1 Chomsky (1965), p. 145.

2 Usually called an "index".

3 Chomsky (1965), p. 146.

${ }^{4}$ Chomsky (1965), p. 146.

5

(ND2 pronoun') is coreferential with $\mathrm{NP}_{1}$ if

1-either $\mathrm{NP}_{1}$ is to the left of $\mathrm{NP}_{2}$ or

$2-\mathrm{NP}_{2}$ is dominated by a clause subordinate to the clause immediately dominating $\mathrm{NP}_{1}$. OPTIONAL (Jackendoff (1968), p.11.)

$6 \mathrm{NP}_{2}$ can be coreferential with $\mathrm{NP}_{1}$ if and only if it is reflexive. OBLIGATORY (Jackendoff (1968), p.6.)

7 See Lakoff (1968), p. 4 . 
8 However, it is debatable to what extent (10a) is ungrammatical. One can certainly argue that (10a) is much less ungrammatical than (10). The reason for this is that in the latter two basically different worlds are concerned (the real world and the world of desires) whereas in the former, the two worlds involved, the world of intentions and the world of desires, are not so widely separated.

9

This was first suggested by Postal (1966).

10

The other two processes which must take place before PRONOMINALIZATION, FEATURE TRANSFER and SURFACE CASE MARKING, are irrelevant to the problem of reference and therefore are not discussed here.

11

12

Chomsky (1965), p. 146.

13

Partee (1973), p. 202.

14 Cf. Lees and Klima (1963), Langacker (1966), Sheppard (1974).

Povzetek

\section{ZAIMKI IN PROBLEM REFERENCE V TRANSFORMACIJSKI SLOVNICI}

Članek obravnava problem reference s stališča dveh osnovnih teorij o zaimkih v olviru transformacijske slovnice, transformacijske in interpretativne. Avtor prikazuje in poskuša kritično ovrednotiti štiri različne pristope $\mathrm{k}$ temu proble$\mathrm{mu}$ : pristop referencialnih indeksov, $k i$ se je uveljavil $v$ transformacijski teoriji o zaimkih, interpretatıvni pristop, ki tvori osnovo interpretativne teorije, t. i. "kontrapar" pristop in formalni pristop.

Pristop referencialnih indeksov temelji na predpostavki, da je referenca označena $v$ globinski strukturi stavkov $s$ pomočjo referencialnih obeležij določenih leksikalnih enot. Po interpretativnem pristopu pa je referenca semantičen koncept in se določa s pomočjo semantičnih pravil interpretacije. Analiza teh dveh pristopov, ki sta $\mathrm{v}$ transformacijski slovnici sicer najbolj razširjena, je razkrila številne slabe strani tako prvega kot drugega pristopa. Pri tem ne gre le za posamezne konkretne primere pronominalizacije in refleksivizacije, ampak tudi za pomembno pomanjkljivost splošnejšega značaja. Niti pristop referencialnih indeksov, niti interpretativni pristop namreč ne vsebuje točne definicije pojma reference. Natančna opredelitev določenega pojma pa je vsekakor nujno potrebna, če naj uspešno rešujemo probleme, ki nastajajo $\mathrm{v}$ zvezi $\mathrm{s}$ tem pojmom.

Pomanjkljivosti dveh zgoraj omenjenih pristopov so dovolj resne, da nastane vprašanje ali je pojem reference sploh relevanten za adekvatno teorijo o zaimkih. Da bi odgovorili na to vprašanje, smo analizirali dva pristopa, ki povsem 
zanikata pomen reference: pristop, $\mathrm{v}$ katerem je pojem reference nadomestil pojem "kontrapar" ("counterpart") in formalni pristop, po katerem je pogoj za pronominalizacijo in refleksivizacijo le formalna, ne pa tudi referencialna identičnost imenskih skupin. Ugotovili smo, da t.i. "kontrapar" pristop zaenkrat predstavlja le parcialen, čeprav obetajoč, poskus, da bi problem reference rešili z uvedbo nekega novega pojma. Formalni pristop pa tak kakršen je, ni sprejemljiv.

Lahko torej zaključimo, da noben izmed obstoječih pristopov $\mathbf{k}$ problemu reference ni povsem zadovoljiv. Možnosti za ustreznejše reševanje tega problema vidimo bodisi v izpopolnjenem "kontrapar" pristopu, bodisi v novem pristopu, ki ga predlagamo $\mathrm{v}$ tem članku in $k i$ upošteva tako formalno kot referencialno identičnost imenskih skupin. Adekvatna teorija o zaimkih namreč mora vključevati pojem reference oziroma odgovarjajoč nadomesten pojem, in ne more temeljiti izključno na formalni jezikovni strukturi. 